\title{
Śraddhā in the Bhagavad Gītā: an investigation on the primeval expressions of the contemporary paradigm on heart-philosophy
}

\author{
Rubens Turci
}

\author{
Correspondence: \\ Programa de Estudos Indianos \\ (PEIND), Universidade do Estado do \\ Rio de Janeiro, Rua São Francisco \\ Xavier 524 sala 9016, Rio de Janeiro \\ - R.J. 20550-900, Brazil
}

\begin{abstract}
Background: The Gitä, as it is well known, is an episode in the Mahäbhärata when the climactic battle is about to begin. Krșna argues in the Gitā that Arjuna should cultivate the necessary śraddhä (faith-in-oneself; mind's serene asceticism toward the heart) in order to overcome his state of doubts and distress.

Discussion: This essay discusses in what manner the contemporary forms of Environmentalism, such as those found in Eco-Dharma and Deep Ecology, have grown straightforward from the heart-philosophy rooted on the concept of śraddhā as dealt with in the Gìtā.

Summary: Śraddhā is a ground to spirituality and environmentalism. No matter one's dogma of faith, it is always possible to display the universal soul force called śraddhā. For, when a sincere Christian, Hindu, Muslim, or even atheist, places his or her trust in that which transcends, what they all display is nothing but a form of the universal śraddhā. Being the element that is common to people of different faiths, śraddhā represents the main category for the understanding of heart-philosophy, which encompasses Theology, Spirituality, Eco-Dharma, and Environmentalism.
\end{abstract}

\section{Introduction}

This essay explores a couple of consequences of my thesis "Sraddhā in the Bhagavad Gìtā" (2007), where I have shown both that term śraddhā keeps in the Gitta its essential meaning of the mind's serene asceticism toward attman (the universal life-principle; the pervading principle in which everything exists, and also that within each living being's heart), and further that, that śraddhā represents the main category for the understanding of the theology of the Gitāa. ${ }^{a}$ Now I intend to discuss in what manner the contemporary forms of Environmentalism, such as those found in Eco-Dharma and Deep Ecology, have grown straightforward from the heart-philosophy, rooted on the concept of śraddha as dealt with in the Gita - a text which paces the carrying out of day-to-day life activities with an existence entirely oriented to the development of a deep awareness of the holistic inner nature of the outer world.

The Bhagavad Gitā, as it is well known, is an episode in the Mahäbhärata when the climactic battle is about to begin. There, Arjuna refuses to fight, and it is Krșna's counsel that will finally convince him. Ultimately, due to his dialogue in the form of a series of kind-hearted theological arguments with Kṛșna, Arjuna is able to overcome his 
paralyzing state of distress. The discipline taught by Krșna leads Arjuna to solve the dichotomy between the duties of the warrior in the pravrtti ${ }^{\mathrm{b}}$ process and those of the disciple seeking spiritual instruction in the nivrtti path. In the Git $\bar{a}$ these two modes represent the two inherent aspects of every single action. Although these processes seem to be separate and opposite, representing the paths of (1) living in the world (pravrtti) and (2) retreating from it (nivrtti), in the Gita $\bar{a}$ they are said to constitute that one single path defined as surrender unto ätman (BhG 18.66 ${ }^{\mathrm{c}}$ ). ${ }^{\mathrm{d}}$ The Gita $\bar{a}$ discusses this issue from the viewpoint of Arjuna's gradual shifting of mindset, ${ }^{\mathrm{e}}$ from his initial egocentric state of distress (guna-para state, as described in BhG 2.67), toward a selfless surrender into the sacred realm of the heart (ätma-para state, as described in BhG 2.58). In the Gïtā, Krșṇa teaches Arjuna to leave behind all personal desires ${ }^{\mathrm{f}}(k \bar{a} m a)$, withdrawing the senses from the sense-objects as a tortoise withdraws its limbs into its shell (BhG 2.58). Even when engaged with the objects of the senses, Arjuna should not lose sight of attman (BhG 2.64). For, when enslaved by the senses, the mind blinds one's judgment (BhG 2.67). Kṛṇa argues that Arjuna should acquire the necessary śraddhā in order to shift from the egocentric sphere (guna-para state) to that of surrender unto ätman (ätma-para state).

The following Hindu poetical standpoint evinces the premises of those living in accordance with the śraddhä-based heart-philosophy:

I experience life as if all things and beings were born from a universal being that interpenetrates and sustains the entire cosmos. I experience life as if we all, from the lowest to the highest being, embodied nothing but a single existence. (Anonymous)

\section{The Bhagavad Gïtā inside the Mahäbhärata}

The Mahäbhärata presents a war-like situation in which the message of the Gïtā provides a contrast between Arjuna's process of pravrtti - the 12 years in the forest, dedicating himself to the practice of tapas (austerity) to get the necessary weapons for the fighting - with Arjuna's process of nivrtti, when he appears in the Gitta eager to step into the spiritual path. The discipline taught by Krșna leads Arjuna to solve the dichotomy between the duties of the warrior in the pravrtti process and those of the disciple seeking spiritual instruction in the nivrtti path. Sraddhā becomes in the Gita $\bar{a}$ the key element for redefining previous concepts and, as a consequence, for solving moral dilemmas.

The common Hindu statement, quoted by Shastri, "Śraddhā is the basis of Śrāddha - śraddhā śrāddhe yato mülam" (1963, 390)," provides the underlying theological frame for structuring the story that links the Gittā with the Mahäbhärata. The śräddha rite (death rite) involves a ritual which bonds people to the deceased by śraddha, in a kind-hearted relation of spirituality and religious fervor. Arjuna's regaining of śraddha in the Gitā, which is a subsection of the Book of Bhișma (Bhișmaparvan), and the heroic ancestor Bhișma's death ritual (śräddha rite) that follow in the Book of Instructions (Anuśāsanaparvan), therefore, are central to the understanding of how the pair śraddhā and śraddha link the different parvans together as a number of different reflections on dharma. After all peace attempts of the Udyogaparvan had failed, dharma is thought of in the following parvans in the context of the battle (dharma-yuddha). The importance of death in ritual terms is clear in each of these different parvans, with the relation of śraddha and śräddha particularly explored in the parvans celebrating commanders' deaths. 
At the very moment one chooses not to follow what ätman indicates, one loses one's śraddha and the ability to recognize dharma. The blind king loses sight of how to rule; Bhissma loses sight of what he needs to protect, and, according to Krșna, Karṇa loses sight of who it is to whom he really owes loyalty. These are the stories of the confusion about dharma in the Mahäbhärata. Those who are ruled by the selfish motives rooted in the individual (ahaṃāra) are not aware of their social and sacred inner nature, or àtman. They are not aware that ātman encompasses the individual, or ahaṃkāra. What the message of Krșna a in the Gittā adds to the story of the Mahābhärata, therefore, is the theological sense that when the sattvic (pure) form of śraddhā is not manifest in a person's heart, the consequence is the deterioration of all forms of life. For, the ability to recognize truth and the laws of nature comes from àtman by means of sattvic śraddhā.

The Gìtā and the Mahäbhärata show how the people who suffer from egocentrism, being oblivious to the principles of the heart-philosophy (ätmic understanding), begin to indulge in lawlessness; with the result there is soon confusion about the nature of the holistic realm in which life itself takes place. Both texts exemplify that, although we are naturally aware of our own existence in the world, we are not always aware of the ātmic realm. One needs to develop the proper śraddhā and live a spiritual life to get àtmic understanding. In the Gìtā, throughout its 18 chapters, Krșna contrasts śraddhā with Arjuna's whining behavior by introducing him to the discipline of orthopraxis $^{\mathrm{h}}$ known as nișkāmakarmayoga - one should put one's heart on the performance of one's mission, without any ulterior motive or interest. ${ }^{\text {i }}$ Arjuna's initial state in the Gita $\bar{a}$ is to be understood as the true dramatic moment of the whole Mahäbhärata - a point where all questioning necessarily leads to some sort of conclusion and practical engagement. Arjuna conveys a metaphysical, social, and political attempt to reach orthopraxis, and the Gitā represents that point of the Mahābhärata where all questions ask for some sort of resolution. The struggle between war and peace represents the moment and opportunity to think again about the meaning of life, law, family ties, righteousness, and above all, the meaning and role of one's own conscience in the larger social process.

The Git $\bar{a}$, then, represents a wholehearted mode of reasoning where the transcendent $\bar{a} t m a n^{j}$ is understood as a way to overcome the manifold world-processes ruled by individualism and selfishness. The Gittā describes a unique and concrete situation, a never-to-be-repeated in reality. The dialogue gives rise to a phenomenology of conscience where different modes of thinking are laid out. The text makes use of myths and customary values to reveal the different aspects of the human psyche that play themselves out in the field of moral philosophy. The Gittä's abstract discussions take place in the field of values, Dharmakșetra. There śraddhā emerges as the truly central category of a heart-philosophy, and reconciles the two distinct types of human activities, defined by the conceptual pair pravrtti (engagement in the affairs of the world) and nivrtti (disengagement from the affairs of the world).

\section{The Gïtā in the Light of Śraddhā}

Although the two paths of pravrtti (engagement) and nivrtti (disengagement) used to be seen in Vedic tradition as separate and opposite, Krșna redefines them as the two complementary aspects of the one discipline of orthopraxis rooted in śraddhā that he is presenting to Arjuna. ${ }^{k}$ Orthopraxis is presented as a matter of an ethical choice, rather than a 
matter of a simple moral decision based on faith and tradition. The Gittā reminds us that the idea of 'doxa' is something of provisional and of relative value; something that should be constantly re-evaluated under the light and higher authority of ätman. This is shown in the Gìtā through Arjuna's legitimate and honest process of doubting. As a real psychological subject (Nara), Arjuna is going through many epistemic transitions, and struggles to realize the ideal epistemic subject (ātman), characterized by Krșṇa (Nārāyaṇa). The Mahābhārata often refers to Kṛșna and Arjuna as Nara-Nārāyaṇa, the nourishers of truth. While the Mahäbhärata showcases the concrete field called Kurukșetra, with Arjuna demonstrating his ability in fulfilling his deeds (pravrtti), the Gittā exhibits his inner struggle to overcome himself and make his mind abide solely in the sacredness of the heart (nivrtti). The Gitta unifies these two different paths of pravrtti and nivrtti. ${ }^{1}$ Arjuna, the warrior in the external process, and Arjuna, the psychological subject seeking real knowledge, are unified by means of the discipline of the realization of ätman, rooted on śraddhā.

Śraddhā is represented in the Gìtā as a ground to spirituality. For, it does not define any 'religion', but that which lies beyond every creed. The etymology of śrad-dhā suggests the general meaning of 'to place one's heart on'. In accordance to the Gita different kinds of devotees (bhakta) are rewarded in accordance with their śraddhā. ${ }^{\mathrm{m}}$ Certainty arises from śraddhā. And that is why śraddhā has sometimes been defined as trusting judgement, or affirmative conviction - āstikya-buddhi, a Vedic ritualistic state of mind, which is totally different from later theistic forms of 'faith'. ${ }^{\mathrm{n}}$ The understanding of śraddhā in the Gìtā as āstikya-buddhi implies entering the sphere of ätman. W.C. Smith, for instance, offers a thorough discussion on the view of śraddhā as āstikya-buddhi and makes it an orientation of yes-ness, an 'awakeness to transcendence' that belongs to the higher visionary self in the 'heart', and not to the rational mind or manas. In his monumental study called Faith and Belief (1979), W. C. Smith comments on this scholarly discussion of the term śraddhā. He starts his analysis noting that the major Vedic commentator Sāyaṇa, and the major commentator on the Gitāa, Sańkara, take śraddhā to mean āstikya-buddhi - a kind of orientation of yes-ness (59). He uses both Minoru Hara (1964) and Paul Hacker to support his understanding that Śankara exegetes the term as śraddhayā āstikyabuddhayā (n. 22, 217), which he translates as 'awakeness to transcendence' (59). Noting that the term is linked with 'buddhi' rather than 'manas' or the 'mind' he concludes that it means more than 'believing' or giving mental assent to something. Furthermore, Smith explains in another note:

śraddhā . . àstikyabuddhir bhakti sahitā. This formula occurs in his [Śan் kara] exegesis of Brhadāranyaka Upanișad, in the section (3:9:20-25) where it is being set forth that the visible forms, life-generative matter, the truth (satyam), and also faith (3:9:21) are dependent upon, are firmly supported by, dwell steadfast in (pratișthitāni bhavanti) the heart - and indeed, the heart alone (hrdaye hy eva). Ed. cit. (above, our ref. 52), p. 484. It may be noted that "heart" here is explicitly interpreted by Śankara as what Westerners would call the mind: namely, the two discriminated organs buddhi and manas together - ibid, p.483, commentary on 3:9:20." (Smith 1979, n. 66, 239)

Manas is the category responsible for the state of doctrinal assent or 'believing', and

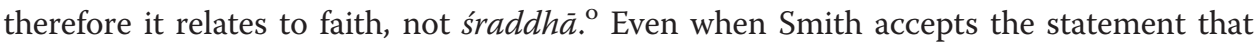


śraddha may be seen as faith, he does not accept the reverse, that 'faith is śraddhä'. The consequence of such a view is the establishment of śraddhā in the Gitā at the very center of spirituality and all philosophical phenomena - heart-philosophy included, as shown next.

\section{Śraddhā and the Heart-Philosophy of the Gità}

Throughout the whole Gitta, Arjuna is led to focus his mind, not in the changeable aspects of the external and material world, but exclusively on that which lies hidden in what we perceive as reality - the a tman, or the unchangeable. ${ }^{\mathrm{p}}$ What the Gitta shows is that anyone is able to 'experience with certitude' the truths of the sacred realm when they discover the highest forms of śraddha - the 'soul force' responsible for putting love in action. It is śraddhā which gives us enough certainty about our intuitions. When one is able to develop śraddha and experience this state oneness dealt with in the Gita by means of the concept of ätman, the mind realizes what has been called the sacredness of nature and of the whole universe.

A similar metaphysical position, where one experiences the world as if through a holy person's eyes is also present in contemporary expressions of heart-philosophy, such as Eco-dharma and Environmentalism, inasmuch as they all assume that the subject is to be thought of as interconnected with the objects, like in the relation of the parts and whole. Arne Naess' main work, Ecology, Community and Lifestyle (Cambridge University Press, 1989), for instance, is deeply ingrained in the heartphilosophy of the Gitā. His focus on deep ecology has given rise to what many have also addressed as Eco-dharma. And that is why one can trace his thought back to the Gittā, where śraddhā can be said to work as a key factor in bringing life to a perfect balance of 'spirituality' and 'materiality'.

As Naess acknowledges in many places, his philosophy, known as Ecosophy $\mathrm{T}$, is rooted in the verse 29 of chapter 6 of the Gittä, where the concept of àtman is outlined. ${ }^{\mathrm{q}}$ When absorbed in the attman, one cannot deviate from the truth. For, the ignorant is he whose ätman is sleeping ${ }^{\mathrm{r}}$ - a fact that manifests itself as one being dispossessed of śraddhā. The 'eco-dharmic' life, in whatever its form, presupposes śraddhā, and śraddhā lights the path, developing itself within that life, where someone gives one's heart and transforms all human affairs in a sacred experience.

Sraddhā, therefore, is what expresses the sovereignty of ätman. Sraddhā is a symbol of illumination and revealer of truth. Arising from the vital stimuli received from the soul (ätman) through its representative (i.e., buddhi, the power of forming and retaining conceptions; intellect, reason, discernment, and so on), śraddhā is a 'material' phenomenon manifested as energy in our body. This energy, even when acknowledged by some scholars as the essential part of the religious phenomenon, is uncomfortably identified with a term coming out of a foreign scripture. Our preference, then, falls on a term such as 'spirituality', which is used as a way to cut away the barriers among different 'faiths', and which now seems to be taking the place of what once we used to call 'religion.' It is with the help of this category 'spirituality' that we can draw together people with different expressions of faith, such as, Tolstoy, Thoreau, Emerson, Luther King, Gandhi, Joan of Arc, Socrates, Lao Tzu, The Buddha, and so on ... . In other words, the term 'spirituality', which somehow translates 'śraddh $\bar{a}$ ' helps us to understand how it is possible to draw a sort of universal Ecosophy, or Eco-dharma, from the Gitāa. For, what the Gittā shows is that 
anyone is able, subjectively, to approach and 'experience with certitude' something of the transcendent ätman, when they discover their own spirituality. No matter one's dogma of faith, it is always possible to display through our deeds the universal soul force called śraddhā. For, when a sincere Christian, Hindu, Muslim, or even atheist, places his or her trust in that which transcends, what they all display is nothing but the highest form of the universal śraddhā. The next section will make this point clearer.

\section{Eco-Dharma: a work in progress toward a New scientific paradigm for reuniting the rational and the spiritual}

It is worthwhile to point out next how the Roman Catholic definition of faith as fides quaerens intellectum, ${ }^{\mathrm{t}}$ where the Latin term 'fides' (faith) implies this urge to accept some 'truths' prior to understanding them, has generated strong debates among philosophers. ${ }^{\text {u }}$ Krishna Sharma, ${ }^{v}$ for instance, denounces the theological exercise undertaken from 17th to the 19th century to safeguard the Christian concept of a personal God:

... the growing trend towards the impersonalization of God in modern European philosophy had posed a serious threat to Christianity which could be counteracted only through a reiteration of faith in the Biblical God, who was personal in nature, and was different from the God of the philosophers" (Sharma 1987, 9).

The consequence, she argues, was the radical separation of religion and philosophy in the Western world. Such a separation was followed by the Christian explanations that religion was "a matter of faith and emotion and not of knowledge and reason" (9). That is to say, the Western differentiation between religion and philosophy was an outcome of the Christian understanding of religion as a dogma of faith in one personal god. The more sophisticated "philosophical explanations of the oneness of God in impersonal terms" were, then, labeled "as either pantheism or monism" (9). Krishna Sharma blames Christian scholars for being interested in keeping the Western division between religion and philosophy, between personal and impersonal concepts of God, and between monism and monotheism" (1987, x).

Paul Hacker comes to the subject with a very different approach. Hacker believes (as all Catholics do in consequence of their definition of faith) that faith must precede understanding, and this is the theological view he assumes when discussing the nature of śraddhā in the Gitā. Sraddhā is to him, so to speak, the preparatory step leading first to knowledge and then to salvation. Hacker explains the meaning of śraddhā through the postulation of a twofold definition: śraddhā would have developed an intellectual constituent, which nowadays may be understood as 'faith', but it would also have kept its foundational ritual constituent. When defining 'intellectual śraddhä' in the Gìtā, he states that śraddhā must precede the knowledge that leads to salvation $(1963,153)$. Yet, although arguing that śraddhā is mainly the acceptance of a doctrine (intellectual śrad$d h \bar{a})$, he is also constrained to acknowledge, when discussing BhG 18.71, that redemption comes primarily from experience, with śraddhā constituting its driving force (154).

The findings of Hacker have not impressed Smith. Smith criticizes those who argue that śraddhā presents many different meanings, "speaking of ritual śraddhā, intellectual śraddhā, moral śraddhā, and so on," in a way that betrays the understanding of its inherent simplicity, as well as of its objects $(1979,61-2)$. For, śraddhā "does not designate 
a relationship to anything," but "indicates rather the attitude or initial act whereby they enter into one or another relation" (62). And further, "It has to do with man's capacity to become involved: the tendency or quality inherent within each person to move outside him or herself and to become engaged" (62). Clearly, one of the scholars Smith is referring is P. Hacker, who also "has made the most thoroughgoing studies of the concept to date," and who indicates by 'faith' (der Glaube) both ästikya-buddhi and śraddhā (n. 28, 222). Smith argues that Hacker has complicated the matter by "including the object of śraddhā in the consideration of the various usages and then exploring the resultant modalities of faith in their intricate variety, in such a way as to obscure what is common to all and is relatively simple." That is to say, because of "the Western tendency to define faith in terms of its objects," Hacker "has clearly been influenced by his prior mental association of faith with intellectual content (an association from his modern Christian heritage)," and the consequence is that he produces a complicated "typology of ritual śraddhā, intellectual śraddhā, etc. (n.40, 227). Smith remarks, then, that śraddhā is not a primarily intellectualistic concept, and therefore, if we manage to "understand śraddhā at all we can understand it in all its Hindu forms" (n. 40, 228). When it comes to Hindu writers, he says, he prefers Rao (1989), who, more cautiously than others, has generally taken śraddhā to mean 'faith', but has also stressed that it is "misleading to translate the word uniformly and without qualification" (n. 28, 222).

As Smith admits, śraddhā "almost constitutes the differentiating characteristic that qualifies any human activity as religious," for it means 'to set one's heart on' since the times of the Rg Veda (61). Further on he adds,

That on which one puts or might put one's heart, in the gamut of India's complex religious life, has been varied. Yet the religious man has been characterized (might we not say, "of course"?) by the fact that he has put his heart on something within it. The term śraddhā is open, in the sense that it does not itself specify or even suggest what it is on which one puts one's heart. The concept as a concept has no particular object, or type of object. (61)

Smith touches here on the issue of the universality of śraddhā, which is not completely dependent on one's faith, for it represents that inner-faith or conviction that allows everyone to see things under the light of the heart, in the ätmic sense presented by Krșna a to Arjuna. As Smith points out, the regular classical Sanskrit word for 'heart' is hrdaya. The term śrad has been motive of some dispute by the linguists. However, "the question is only as to whether śrad-/*kred is "heart', the visceral organ," and has nothing to do with the figurative sense in which it is being used here. (n. 35, 223-4)

As Smith puts it, śraddhā "contrasts with a mind that is wandering" (63); it implies "involvement" with our own reality. It "denotes a way of doing things" in "the way an intellectualist relates his mind and himself to the truth" (64). There is no instance of śraddhā where the notion of "putting the heart" "is not relevant and appropriate" (n. 44, 229). That is to say, "once it has been affirmed that śraddhā means 'placing one's heart on', there is in a sense nothing more to be said" (62). Spirituality, whatever its form, presupposes śraddhā, and śraddhā lights the path, developing itself within that life, where someone gives one's heart. As a consequence, this truth transcends what is 'religious' and transforms all human affairs, leading to Deep Ecology, Environmentalism, and Eco-dharma, as A. Naess and others have described it. 
In order to help to end this quarrel about the phrase 'fides quaerens intellectum', which imposes a passive acceptance of the dogmas of 'faith', I want to point out, therefore, that śraddhā seems to mean more than faith. It means, at least, faith plus prudence. As a matter of fact, I am inclined to believe that the meaning of śraddhā in the Gita encompasses the Seven Virtues adopted by the Catholic Church Fathers: Prudence, Justice, Temperance, Courage, Faith, Hope, and Compassion. This means, perhaps, that to bring up to date the true meaning of the phrase 'fides quaerens intellectum', as foreseen by the medieval Catholic Church Fathers, it would be enough to replace the term 'fides' by the more accurate term 'śraddhä'. For, the half-breed expression 'śraddha quaerens intellectum' passes both the scientific and spiritual requirements. Representing a kind of experimental certainty and trust, the expression 'śraddhā quaerens intellectum' seems to relate to both, the Cartesian Cogito, ${ }^{\mathrm{w}}$ and the Baconian Method. ${ }^{\mathrm{x}}$ One may even consider that this expression represents, indeed, a fair candidate as the new paradigm of contemporary Heart-Philosophy and Eco-dharma. For, the meaning it conveys implies the so-called reconciliation of reason and spirituality (Fritjof Capra states that "ecology and spirituality are fundamentally connected, because deep ecological awareness, ultimately, is spiritual awareness." (qtd. in Dudley 2005: 21)) intended at least since Blaise Pascal's saying, "The heart has its reasons which reason knows nothing of... We know the truth not only by the reason, but by the heart."

\section{Conclusion}

Besides the complex philosophical and mythological elements and the ritual theory which frames the Gìtā in the context of the Mahäbhärata, one cannot disregard the fact that what explains how the different characters respond differently to the same ethical dilemmas is śraddhā. Sraddhā also provides the underlying unity of the two texts. Furthermore, śraddha expresses the gradual shift from the sphere of the individual to that of the collective, representing an altruistic 'placing of the heart' on righteous expressions of activism, which are supposed to be free from any selfish interest. Ätmic detachment and altruism are triggered by means of śraddha $\bar{a}$, which enables one to take the righteous deeds to the heart (ātman).

When Naess coined the expression "Deep Ecology," he had in mind a new paradigm shift that could bridge the huge gap in the Western world between the realms of spirituality and science. One may but hint at the formula Naess was trying to grasp - perhaps the one we have captured under the half-breed expression "śraddhā quaerens intellectum."

The conclusion, then, is that śraddhä, being the element that is common to people of different faiths, represents the main category for the understanding of heart-philosophy, which encompasses Theology, Spirituality, Eco-Dharma, and Environmentalism. Eventually, by means of śraddhā, we come to trust our own ability to identify what constitutes the truth, and this is just a contemporary way of restating what St. Anselm had tried to convey through the expression "fides quaerens intellectum."

\section{Endnotes}

an "Śraddhā in the Bhagavad Gittā" (Hamilton: McMaster University, Ph. D. diss., 2007) I discuss how śraddhā (heart force or love-in-action; self-reliance, faith-in-oneself, and also enthusiasm) appears in order with the Vedic usage, and opens the person to contact with the soul-force, which drives the whole universe. I have shown in what ways 
śraddhā links the Gittà to the Mahäbhärata and reveals in both texts the centrality of the sacred and sacredness (dharma, the sense of spirituality and holiness) hidden in nature itself. I have also discussed some theological implications of this view and considered how śraddhā can manifest through a person's heart. The Latin term 'credere', which is usually rendered by the English term 'creed', can be etymologically traced back to the same Sanskrit root as the term 'śraddhä'. The metaphorical sense of 'putting one's heart on' points to the common origin of these terms both rooted in the primitive Indo-European term kred-dhe. W.C. Smith exemplifies this matter in a note with the help of the Christian saying, "Where your treasure is, there will your heart be also" (Mathew 6:21 and Luke 12:34). See W.C. Smith's Faith and Belief (Princeton: Princeton University Press, 1979: n.35, 223).

${ }^{\mathrm{b}}$ The tendency one shows to express oneself through external action is known as pravrtti, and the tendency one shows to refrain from external activity is known as nivrtti. In other words, pravrtti denotes active functioning in the external world, whereas nivrtti denotes a kind of disengagement from the world, associated with a spiritual discipline and leading from saṃsāra (this world) toward nirvāṇa (salvation).

'‘BhG 18.66'stands for 'verse 66 of chapter 18 of the Bhagavad Gitā.'

${ }^{\mathrm{d}}$ This solution is unexpected. Śankara, for instance, who reads pravrtti and nivrtti as karma mārga (path of action) and saminyāsa märga (path of non-action) respectively, does not consider the meaning intended by Krșna, where 'pravrtti' might express actions worth pursuing, and 'nivrtt' the actions to be avoided. Yet, these meanings are implied in the context of the whole text, and more Specifically in the discussion starting in BhG 18.40. For, according to Krșna's previous arguments, one can infer that saṃsāra (the existence, manifested in the form of movement and actions) presents some sort of reality and cannot be completely fashioned by avidyā. According to Śańkara, however, calling Arjuna a samnyāsin is only a special deference meant to praise his action (BhG 18.17), considering that he was not fit for the higher Sāmkhya. Sańkara disregards the fact that BhG 18.30 reintroduces the question about the meaning of the terms pravrtti and nivrtti precisely in order to redefine what a real samnyāsin is. Śankara simply reads BhG 18.30 as if 'pravrtti' meant 'bondage' and 'nivrtti', liberation. He says, "That which knows action, "pravrtti", which leads to bondage, the path of Works, and inaction, "nivrtti", which leads to mokșa (Liberation), the path of saminyāsa”. See Śañkara's Gita Bhasya, translation by C. V. Ramachandra Aiyar (Bombay: Bharatiya Vidya. Bhavan, 1988: 573). As I have shown in my thesis, however, the Gittā makes use of the concept of śraddhā to integrate the Vedic karma-mārga thesis and the Upanișadic jĩāna-märga antithesis. The newness of the argument of the Gittā lies precisely in this synthesis called jñannakarmasamuccaya-vada, which allows Arjuna to learn different views on the science of being, and to shift from his momentary state of an aśraddadhāna (one dispossessed of śraddhā) to that of a śraddhāvant (one possessed of śraddhā).

'The issue of Arjuna's transformation has recently attracted some scholarly comment, but most scholars do not discuss the role of śraddhā in this transformation. When the Gittà starts, Arjuna is a devotee (bhakta) without śraddhā, and, when the Gitē ends, Arjuna is a devotee with śraddhā. That is to say, one can be dejected and still be a devotee. However, one cannot be depressed and full of śraddha at the same time. This distinction between śraddhā and bhakti helps one to follow Arjuna's gradual shifting of mindset throughout the text. 
${ }^{\mathrm{f}} \mathrm{We}$ should be careful in order not to be fooled by the phrase 'personal desire'. 'Personal desire' is not to be taken in the general sense of 'desire' as used, for instance, by Herbert Marcuse in his One Dimensional Man (Ark Paperbacks, 1964). For, of course, desire can never be fully eradicated from oneself.

${ }^{\mathrm{g}}$ See Dakshina Ranjan Shastri, Origin and Development of the Rituals of Ancestor Worship in India (Calcutta: Bookland Private Limited, 1963).

hIn a sense, what the Gitē shows is that orthodoxy leads to orthopraxis; orthopraxis to renewed orthodoxy, and so on, in a chain of events without end or beginning. 'Orthopraxis' is the theological term for 'correct practice', and is not to be taken as 'inflexible practice of rituals and dharma'. On the contrary, orthopraxis is to be considered the result of one being confident and full of spiritual enthusiasm (śraddhā). Resulting from śraddhā, orthopraxis represents something deeper than the Western understanding of it as 'lifestyle'. One could say that the Gitä's orthopraxis somehow resembles the Buddhist eightfold path, with the differences between the Buddha and Krșna's teachings representing mostly the different audiences they have addressed and their respective 'doxas' - the first addressing the orthodoxy of the àstikas (those who accept the authority of the Vedas), and the second, that of the nästikas (those who does not accept the authority of the Vedas). The Buddhist eightfold path is usually classified under three main headings: panna or wisdom (1. right view; 2. right understanding), sila or moral activity (3. right speech; 4. right action, and 5. right livelihood), and samädhi or contemplation (6. right effort; 7. mindfulness, and 8. right concentration).

'Nișkāma, or 'non-personal desire', is what is required from our actions, from the viewpoint of our interest or desire to profit from their outcome. One should act for the sake of the goodness of the action in itself, and not for any other personal reason. For, being disciplined and learning to detach oneself from the consequences or rewards of one's actions separate those who are ready for the discipline of orthopraxis from those who are not ready yet.

'See F. O. Schrader, "Über Bhavavadgitā" (ZDMG 64, 1910: 336-340). Schrader is of the opinion that the Gita $\bar{a}$ is placing an emphasis on the experiential knowledge about the ätman. Moreover, he also reminds us that the ātmavidyā (science of ātman) nullifies one's dependency to the Vedas.

${ }^{k}$ See P. Hacker "Sraddha" (Wiener Zeitschrift fur die Kunde Sudasiens 3, 1963: 151-189), and idem, Paul Hacker Kleine Schriften - Herausgegeben von Lambert Schmithausen (Wiesbaden: Franz Steiner, 1978). Hacker's argument that there seems to exist two kinds of śraddhā, one intellectual, belonging to the jũānamärga, and another ritualistic, belonging to the karmamārga also suggests that the two paths of forth-going (pravrtti) and return (nivirti) represent in the Gittā the one discipline based on śraddhā.

${ }^{1}$ In the Gïtā, both processes are made one through the discipline of nișkāmakarma. For selfishness (svārtha) is what enslaves one's actions, either in the form of pravrtti, or nivrtti. Therefore, non-personal pravrtti and nivrtti together, as defined in the Gitāa, is what constitutes orthopraxis.

${ }^{\mathrm{m}}$ For further details see the whole discussion on my thesis. Here it is enough to point out what Paul Hacker, Das Gupta, and Minoru Hara have already said. Paul Hacker argues that the practice of bhakti demands a prior faith (śraddhā) in the mythological tradition. He acknowledges that śraddha comes close to bhakti in some passages, and 
that the commentator Madhusūdana, in his discussion of BG 7.21, equates śraddhā to bhakti. Hacker reminds us, however, that in Saanọilya Bhaktisūtras 22-4 such equivalence is expressly denied. These Śāndilya sütras demonstrate the difference between śraddhä and bhakti with a logical argument: sütra 22 states that śraddhā is the common element of all paths, bhakti included; sütra 23 states that the identity of śraddhā and bhakti, therefore, would lead to infinite regression, and sütra 24 , then, states that it is impossible to equate both terms. Das Gupta (1930, 315-333 and 487513) has shown that the meaning of śraddhā in the Vedic Samphitās cannot be said to be very close to that of bhakti. Minoru Hara has shown that in the Gita a bhakti can be seen as related to dependence on a theistic god, whereas this is not the case with śraddhā. In his view it preserves a more traditional concept of religion, quite independent of theism. As Das Gupta sees it, bhakti has a personal connotation and implies a human relation, whereas śraddhā is a non-personal and neutral principle, resulting from a ritual context.

${ }^{\mathrm{n}}$ Those who propose śraddha as a synonym of bhakti could only do so if they held the complete identity of ätman and Krșna. As a consequence, they will also argue that Arjuna's ultimate aim is to realise the supreme Godhead in a 'theistic' way. We find a similar view in St. Jean-Baptiste-Marie Vianney's Catechism on The Holy Spirit: "When we have the Holy Spirit, the heart expands; it bathes itself in divine love. The contrast between the experiential concepts of śraddhā and bhakti actually corresponds to the contrast between what one believes the terms ätman and Krșna designate as objects. Love towards the personal deity Krșna; however, seems to represent nothing but an instance of Arjuna's universal love, grounded on ätman.

${ }^{\circ}$ To be precise, śraddhā combines in itself the unflinching devotion and a deeprooted and clear understanding; it is both intellectual and mental. As it is seen, śraddha is difficult to be translated into any single word in any modern language. In the Saivagama-s we find in the context of initiation (dīkșā), that only he who possesses bhakti and śraddhā will get the saving dīkșā. One may note the redundant usage here: bhakti and śraddhä. Even when it is possible to be a devotee (bhakta) without śraddha, the reverse, to be endowed with śraddha without bhakti, is not possible. That is to say, bhakti is a prerequisite to the more essential category śraddha.

${ }^{\mathrm{P}}$ The man of restraint is wakeful in that which is the night of all beings, and the time in which all beings are wakeful is the night of the sage who sees [or perceives the light of àtman] (BhG 2.69).

${ }^{\mathrm{q}} \mathrm{BhG}$ 6.29: He whose ätman is disciplined by yoga, seeing the same in all around, sees ätman in everything, and everything in ätman.

${ }^{\mathrm{r}} \mathrm{K}$ rșna is using in BhG 4.40 the same metaphor he had used in BhG 2.69: the sage is awake to ätman, which is the night of the other beings.

${ }^{s}$ Rembert Lutjeharms who insists in translating 'śraddhā' as 'faith' presents a slightest different view in his recent "FIRST FAITH: ON THE MEANING AND ROLE OF ŚRADDHĀ IN CAITANYA VAIṢNAVA THOUGHT" (ISKCON Studies Journal, Vol. 2, 2014: 71-110). He argues that "the notion of faith (śraddhā)" is "closely linked to 'conversion" (105), and concludes that the devotee starts "with a faith in devotion (śraddhā)," and "progresses as his faith in devotional practices is strengthened by his systematic study of devotional scriptures" (106). 
${ }^{t}$ Although faith is contrary to reasoning, Christian thinkers still base mostly of their philosophical thought on St. Anselm's assertion that faith represents the real pre-requirement to knowledge and self-understanding - 'fides quaerens intellectum'.

"See, for instance, Kai Nielsen's "Wittgensteinian Fideism" (Philosophy v. 42 1967: 191-209 [reprinted in The Philosophy of Wittgenstein v. 14. Aesthetics, Ethics, and Religion), edited by J. Canfield]). Wittgensteinian fideism reveals the fallacy involved in the acceptance of the dogmas, which supposedly constitute the final truths of humankind.

${ }^{v}$ See Krishna Sharma, Bhakti and the Bhakti Movement - A New Perspective (New Delhi: Munshiram Manoharlal, 1987).

'The Latin phrase 'cogito ergo sum' (I think, therefore I am) is acknowledged in Western philosophy as a foundation for all rational knowledge. It was stated in French on Descartes' Discourse on the Method (1637), and in Latin in his Principles of Philosophy (1644).

${ }^{\mathrm{x}}$ The Baconian method was proposed in Bacon's Novum Organum (1620). While Descartes have put forward the deductive process of reasoning used in science, Bacon puts forward the inductive reasoning. Together, they have given raise to the scientific method. Scientific investigation involves the observation of phenomena, the formulation of a hypothesis, experimentation, and a conclusion that validates or modifies the hypothesis. Both, Descartes and Bacon, have based their theories on the results of men such as Copernicus and Galileo, who have doubted the dogmas of faith.

Competing interests

The author declares that he has no competing interests.

Received: 6 July 2014 Accepted: 14 January 2015

Published online: 28 February 2015

References

Das Gupta, Mrinal, "Śraddhā and Bhakti in Vedic Literature." Indian Quarterly 6 (1930), 315-333 and 487-513.

Dudley, Nigel, Liza Higgins-Zogib, \& Stephanie Mansourian. 2005. Beyond Belief: Linking Faiths and Protected Areas to Support Biodiversity Conservation, Switzerland \& United Kingdom: WWF.ARC. Available at http://wwf.panda.org/ about_our_earth/all_publications/?58880/Beyond-Belief-Linking-faiths-and-protected-areas-for-biodiversityconservation. Accessed January 31, 2015.

Hacker, Paul. 1963. "Sraddha". 1963. Wiener Zeitschrift fur die Kunde Sudasiens 3: 151-189.

Hacker, Paul. 1978. Paul Hacker Kleine Schriften - Herausgegeben von Lambert Schmithausen. Wiesbaden: Franz Steiner.

Hara, Minoru. 1964. NOTE ON TWO SANSKRIT TERMS - bhakti and śraddhā. Indo-Iranian Journal VII: 124-145.

Lutjeharms, Rembert. 2014. FIRST FAITH: ON THE MEANING AND ROLE OF ŚRADDHĀ IN CAITANYA VAIȘNAVA THOUGHT. ISKCON Studies Journal 2: 71-110.

Marcuse, Herbert. 1964. One-dimensional Man: studies in ideology of advanced industrial society. Ark Paperbacks; reprint. London: Routledge (1991).

Naess, Arne. 1989. Ecology. Community and Lifestyle: Cambridge University Press.

Nielsen, Kai. 1967. Wittgensteinian Fideism". Philosophy 42: 191-209.

Rao, Seshagiri K L. 1971. The Concept of Sraddha. Patiala: Roy Publishers

Rao, Seshagiri K L 1989. "Sri Aurobindo on the Types of Sraddha (Faith) in the Gita" Journal of South Asian Literature 24.1: $168-178$

Schrader, Friedrich Otto. 1910. Über Bhavavadgìtā. ZDMG 64: 336-340.

Sharma, Krishna. 1987. Bhakti and the Bhakti Movement - A New Perspective. New Delhi: Munshiram Manoharlal.

Shastri, Dakshina Ranjan. 1963. Origin and Development of the Rituals of Ancestor Worship in India. Calcutta: Bookland Private Limited.

Smith, WC. 1979. Faith and belief. Princeton, N.J.: Princeton University Press.

Sri Sankara's Gita Bhasya (trans. Aiyar, C. V. R). 1988. Bombay: Bharatiya Vidya Bhavan.

Turci, Rubens. 2007. Śraddhā in the Bhagavad Gītā. Hamilton: McMaster University, Ph. D. diss. 